\title{
Independent Board, Audit Committee, Risk Committee, the Meeting Attendance level and Its Impact on the Performance: A Study of Listed Banks in Indonesia
}

\author{
Te-Kuang Chou ${ }^{1} \&$ Agung Dharmawan Buchdadi ${ }^{2}$ \\ ${ }^{1}$ Professor of Finance in College of Business, Southern Taiwan University of Science and Technology, Taiwan \\ ${ }^{2}$ Graduate Student of College of Business, Southern Taiwan University of Science and Technology, Taiwan \\ Correspondence: Agung Dharmawan Buchdadi, Graduate Student of College of Business, Southern Taiwan \\ University of Science and Technology, Taiwan. Tel: 886-98-137-9460.
}

Received: April 4, 2017

Accepted: April 26, 2017

Online Published: May 3, 2017

doi:10.5430/ijba.v8n3p24

URL: https://doi.org/10.5430/ijba.v8n3p24

\begin{abstract}
This study determines the effect of good corporate governance on the performance of banks in Indonesia. The variables used are independent board (IB), the annual board meeting (BM), the percentage of annual board of director meeting attendance, the annual board-executive meeting (BEM), the percentage of annual board-executive meeting attendance, audit committee (AC), audit committee meeting (ACM), the percentage of annual audit committee meeting attendance, risk committee (RC), risk committee meeting (RCM), and the percentage of annual risk committee meeting attendance. The analysis technique employed in this study is two-stage least square (2SLS) panel data regression using return on asset (ROA), net interest margin ratio (NIM), and Tobin's Q as the proxies of bank performance. The data used are listed bank in Indonesia Capital Market between 2013 and 2015. The findings reveal that the independent board has a positive impact on net interest margin among the big scale bank. However, among the small scale bank the independent board of directors has the positive impact on the market value, but they will have the lack of information that could obstruct the accounting based profit of the bank. Moreover, the findings of this study also explain the important role of meeting attendance for the accounting based profitability of the bank. This study also found the critical role of the audit committee in the banking industry.
\end{abstract}

Keywords: audit committee, bank performance, independent board, Indonesia, risk committee, meeting attendance

JEL Classification: G21, G30, G34

\section{Introduction}

Learning from the severe crises in the banking industry, the Indonesian government developed Arsitektur Perbankan Indonesia (Indonesian Banking Architecture, API) which is a basic framework of Indonesia banking system for the next 5 to 10 years. This framework was launched on 9th January 2004 (Indonesia, 2016a). One of the programs listed in this framework is a quality improvement of banking management and operations by implementing good corporate governance starting from 2004 (Indonesia, 2016b). From the central bank regulation no 4/8/PBI/2006 it is mentioned about the importance of the independence board of director. The bank asked to have at least $50 \%$ of the independent board of director. Furthermore, the board of directors has to make audit committee, risk monitoring committee, and the remuneration and nomination committee, reporting the number of meeting and attendance report in the annual report (Indonesia, 2006).

The primary reason for implementing corporate governance is the agency problem which is the separation between control and ownership (John \& Senbet, 1998). The shareholders prefer to make a contract to managers that take appropriate actions to maximize their wealth. Thus, whether a company has not implemented a good corporate governance mechanism, the manager could make a decision in managing the business in line with their own interest. Meanwhile, whether the company applies a good corporate governance mechanism, the decision will be monitored and controlled by the board of directors. Then, the decision and strategy will in line with the goal made by the shareholders. In agency theory, the governance mechanisms construct monitoring, giving incentives, and ownership structure in the company (Coles, McWilliams, \& Sen, 2001). 
Furthermore, Pradhan, Arvin, Hall, and Bahmani (2014) mentioned about the importance banking sector development in determining the long run development in ASEAN regional countries. It is in line with the suggestion of Claessens and Yurtoglu ( 2013) which encourages more research on corporate governance role of banks. Bank as the creditor of a company could play as the agent to another investor. So, enhancing the corporate governance of banks may be effective in improving overall governance.

Many previous studies are examining good corporate governance (GCG) practice in many industries among many countries. Yet, as long as we know it is just a little research for examining GCG practice in the banking sector in Indonesia. We noted the recent study is conducted by Markonah, Cahaya, and Riwayati (2016) that found ROE and Size have a significant negative relationship to GCG index. In addition, ROA and fixed asset variables have a significant positive relationship to GCG index. Realizing the importance of GCG practice in the banking industry and trying to broaden the previous research, we seek to conduct research in studying the GCG practice in the banking sector in Indonesia. We will examine the impact of GCG practice that issued by the central bank on the regulation of banking performance such as the impact of board independent, the impact of the board meeting, and the impact of committees under the supervision of the board of director. Hopefully, the results of this study can be used as consideration in the development of good corporate governance in developing countries, as concluded in previous studies that the research results GC in developed countries cannot be applied directly as a result of political, economic, technological and cultural differences (Mulili \& Wong, 2011).

\section{Literature Review and Hypothesis Development}

The condition of governance mechanism banking industry is more complicated than other industry. It is mentioned that in practice bank corporate governance focuses on two areas: ownership structure and governance, and internal governance mechanisms. Internal governance mechanisms are including the board of directors, compensation of executives, and internal control (Tan, 2014). Mangunyi (2011) study on the bank in Kenya mentioned that better corporate governance leads to better firm performance. In addition, Salama and Putnam (2013) findings reveal that that globally diversified companies with higher quality corporate governance perform better and are traded at higher values. The study utilizes some variables to measure the quality of corporate governance: 1) board of directors' quality (leadership structure, board size, board meetings, board independence, busyness of board, and board-shares ownership); 2) audit committee quality (audit committee size and audit committee meetings); and 3) compensation committee quality (compensation committee size and compensation committee meetings). Then, this study will focus examining the impact of board independence, the impact of the board meeting, and the impact of committees under the supervision of the board of director on bank performance.

In addition, this study will also cite the recent research of bank performance in Indonesia which were conducted by Arafat et al. (2013) as well as Chou and Buchdadi (2016). We will use the determinant of bank performance in Indonesia as the control variables. From these studies, we noted that NPL and BOPO have an important role in explaining the bank performance which was measured using ROA and NIM. Both studies found that NPL has a significant negative relationship with ROA. This argument is aligned with some researches (Dincer, Gencer, Orhan, \& Sahinbas, 2011; Roman \& Şargu, 2013). However, Arafat et al. found a different result with Chou and Buchdadi when the performance measured by NIM. Furthermore, we add Tobin's Q variable for measuring market based firm performance as it is frequently used in corporate governance research (Brick \& Chidambaran, 2010). The last control variable used in this study is the asset which is commonly employed in corporate governance research (Tao \& Hutchinson, 2013)

\subsection{Effects of Independent Board of Directors on Bank Performance}

It is mentioned in Al-Najjar (2014) that independent director will have a better monitoring role in the firm which will make a positive impact on company performance. The independent board will bring their connection and expertise to make the firm have the better achievement. In addition, some studies found a positive relationship between board independence and firm performance (Duru, Iyengar, \& Zampelli, 2015; Mashayekhi \& Bazaz, 2008; Müller, 2014). In addition, we noted from two research that board independence and number board meeting variables are positive significant to the bank performance (Liang, Xu, \& Jiraporn, 2013; Liu, Miletkov, Wei, \& Yang, 2015; Zhu, Ye, Tucker, \& Chan, 2016) Then, this study tries examining the effect of board independent and board meeting on bank performance in Indonesia.

For examining the impact of the independent board, we modified the variable definition used by Duru et al. (2015). Despite we use the proportion of independent board for measuring the independent board variable, we use the natural logarithmic of the independent board as it employed in Duru et al. (2015) for measuring board size. The reason for modifying this variable is regarding the regulation that the proportion of independent board for the bank is at least 
$50 \%$ (Indonesia, 2006). Then, we got the variability of this proportion is relative not high. So, we prefer to use the number of the independent board which has more variability among the bank.

Even though we found one study (Cavaco, Crifo, Rebérioux, \& Roudaut, 2017) argue independent board is negatively correlated with operating performance, we propose the positive association regarding the board of directors in banking have to pass fit and proffer test conduct by the central bank. Then, the board of directors will have the skills and knowledge needed in the banking industry. Considering these results, we posit the first hypotheses as follow:

H1: Board independence will positively associated with bank performance

\subsection{Effect of Board of Directors Meeting on Bank Performance}

One of the easiest ways to evaluate the board performance is by counted their attendance at the board meeting. The more meeting they have, the more intense they do their role in monitoring and advice the firm. Bank Indonesia regulation use the attendance record as the proxy that the board member have adequate time to play the role of the board of director (Indonesia, 2006). In addition, from the previous research, we noted from Chou, Chung, and Yin (2013) that board meeting has a positive impact on the firm performance. However, it is mentioned that the board should be at the meeting by themselves not by the representative.

Chou, Chung, and Yin (2013) examine the board meeting variable by using two proxies. The first proxy is the percentage of board meetings attended by a director him/herself and the second is the percentage of board meetings attended by representatives authorized by a director. Meanwhile, the regulation of Bank Indonesia stated that at least the board of director makes 4 (four) meetings annually which at least 2 (two) times attended by the total member of the board of directors (Indonesia, 2006). From the annual report of the bank, we noted there is three information of board meeting on it. The first is the number of meeting internally of the board of director. The second is the number of meeting board of director with executives. The last is the attendance level of both kind meeting mentioned before. Then, in this study, we propose two proxies for these two kinds of board meetings. Inspired from Chou, Chung, and Yin (2013), we use the percentage of board attendance of internal board and board-executive meeting. Regarding the results of previous studies, we posit the hypotheses as follow:

H2: Board of directors meeting variable will positively associated with bank performance.

H3: Board of directors-executive meeting variable will positively associated with bank performance.

H4: The percentage attendance of board of directors meeting variable will positively associated with bank performance.

H5: The percentage attendance of board of directors-executive meeting variable will positively associated with bank performance.

\subsection{Effect of Committee on Bank Performance}

According to the bank Indonesia regulation, board of directors of the bank have to organize at least 3 committees, i.e. audit committee, risk monitoring committee, and remuneration and nomination committee (Indonesia, 2006). Both audit committee and risk monitoring committee have to build by hiring independent member that have no relationship to the bank. We noted some research examining the committee under the board of director body such as Tao and Hutchinson (2013) found that the composition of the risk and compensation committees is positively associated with risk, which, in turn, is associated with firm performance. Meanwhile, Salim; Arjomandi; and Seufert (2016) found that committee meetings have robustly significant and positive effects on efficiency. In addition, Munisi and Randoy (2013) mentioned that for publicly listed companies across Sub-Saharan African countries the audit committee sub-indices are associated positively and significantly with accounting performance. However, the audit committee sub-indices are associated negatively and significantly with market valuation. In this study, the audit committee sub-indices are including the independence of committee and reporting of the committee meeting. So, in this study, we will examine the impact to firm performance similar way as board of directors meeting variable. Tao and Hutchinson (2013) used committee characteristic (size, the proportion of independent member, experience and activity) for this variable. Meanwhile, Salim; Arjomandi; and Seufert (2016) used committee meeting for explaining the bank efficiency. So, we will use 3 (three) proxies for these three committee bodies. The first is a number of committee member, the second is the number of annual committee meetings, and the last is the percentage of committee meeting attendance. Then, the hypothesis build in this model are:

H6: The number of audit committee member will positively associated with bank performance.

H7: The number of annual audit committee meeting will positively associated with bank performance. 
H8: The percentage of attendance of annual audit committee meeting will positively associated with bank performance.

H9: The number of risk committee member will positively associated with bank performance.

H10: The number of annual risk committee meeting will positively associated with bank performance.

H11: The percentage of attendance of annual risk committee meeting will positively associated with bank performance

\section{Methodology}

\subsection{Data}

The time span for this study is 2013 to 2015 . The sample populations are listed banks in Indonesia capital market. The data used in this study are obtained from published annual report of the bank. The numbers of banks included in the sample are 38 banks which will divide into 2 categories as big bank and small bank. This asset class separation is done in accordance with the regulation of Bank Central Indonesia (Nomor 8/4/PBI/2006 article 76; Indonesia, 2006). The bank is considered small bank whether the asset value is less than IDR 10 trillion (approximately: USD 715.000), while the bank which has asset value more than IDR 10 trillion is categorized as a big bank.

\subsection{Definition of Variables}

The variables used in this study are presented in Table 1.

Table 1. Definition of variables

\begin{tabular}{|c|c|c|}
\hline Dependent Variable & Definition & Cited from \\
\hline Return on Assets (ROA) & a ratio between the company earning and its total assets & (Chou \& Buchdadi, 2016) \\
\hline Net Interest Margin (NIM) & $\begin{array}{l}\text { a ratio between the spread between interest gain from the loan } \\
\text { and interest payment from debt with its interest bearing assets. }\end{array}$ & (Chou \& Buchdadi, 2016) \\
\hline Tobin's Q & $\begin{array}{l}\text { a ratio of the market value of the firm to the book-value of } \\
\text { total assets }\end{array}$ & $\begin{array}{l}\text { (Brick \& Chidambaran, } \\
\text { 2010) }\end{array}$ \\
\hline \multicolumn{3}{|l|}{ Independent variable } \\
\hline Independent Board (IB) & $\begin{array}{l}\text { the natural logarithmic of independent board member in the } \\
\text { board of director }\end{array}$ & $\begin{array}{l}\text { Modified from (Duru et al., } \\
\text { 2015) }\end{array}$ \\
\hline Board meeting (BM) & The number of annual meeting of board directors & $\begin{array}{l}\text { (Riaz, Liu, \& Ahmad, } \\
\text { 2016) }\end{array}$ \\
\hline Board-Executive Meeting (BEM) & $\begin{array}{l}\text { The number of annual meeting among board of directors and } \\
\text { executives }\end{array}$ & Proposed for this study \\
\hline $\begin{array}{l}\% \text { Board Meeting Attendance (\% } \\
\text { BM Att) }\end{array}$ & $\begin{array}{l}\text { the percentage of board meeting attended by the board of } \\
\text { directors }\end{array}$ & (H. I. Chou et al., 2013) \\
\hline $\begin{array}{l}\% \text { Board- Executive Meeting } \\
\text { Attendance (\% BEM Att) }\end{array}$ & $\begin{array}{l}\text { the percentage of board and executives meeting attended by } \\
\text { the board of directors }\end{array}$ & $\begin{array}{l}\text { Modified from (H. I. Chou } \\
\text { et al., 2013) }\end{array}$ \\
\hline Audit Committee (AC) & The number of audit committee member & (Tao \& Hutchinson, 2013) \\
\hline $\begin{array}{ll}\text { Audit } & \text { Committee } \\
(\mathrm{ACM}) & \text { Meeting }\end{array}$ & The number of annual meeting of audit Committee & $\begin{array}{l}\text { (Salim et al., 2016; Tao \& } \\
\text { Hutchinson, 2013) }\end{array}$ \\
\hline $\begin{array}{l}\% \text { Audit Committee Meeting } \\
\text { Attendance (\% ACM Att) }\end{array}$ & $\begin{array}{l}\text { the percentage of audit committee meeting attended by the } \\
\text { member of the risk committee }\end{array}$ & $\begin{array}{l}\text { Modified from (H. I. Chou } \\
\text { et al., 2013) }\end{array}$ \\
\hline Risk Committee (RC) & The number of risk committee member & (Tao \& Hutchinson, 2013) \\
\hline Risk Committee Meeting (RCM) & The number of annual meeting of risk Committee & $\begin{array}{l}\text { (Salim et al., 2016; Tao \& } \\
\text { Hutchinson, 2013) }\end{array}$ \\
\hline $\begin{array}{l}\% \text { Risk Committee Meeting } \\
\text { Attendance (\% RCM Att) }\end{array}$ & $\begin{array}{l}\text { the percentage of risk committee meeting attended by the } \\
\text { member of the risk committee }\end{array}$ & $\begin{array}{l}\text { Modified from (H. I. Chou } \\
\text { et al., 2013) }\end{array}$ \\
\hline Non-Performing Loan (NPL) & the amount money of loan that is in default or close to default. & (Chou \& Buchdadi, 2016) \\
\hline $\begin{array}{l}\text { Operational Expense ratio } \\
\text { (BOPO) }\end{array}$ & a ratio between operational expense and operational revenue. & (Chou \& Buchdadi, 2016) \\
\hline Asset (LNAsset) & The natural log of firms' total assets & (Tao \& Hutchinson, 2013) \\
\hline
\end{tabular}




\subsection{Models}

Using the ten corporate governance variables, we applied two-stage least squares (2SLS) panel data regression models. The 2SLS used to control any endogeneity problems between corporate governance factors and firm performance (Al-Najjar, 2014; Schultz, Tan, \& Walsh, 2010).

The equation models for this study are:

$$
\text { Performance }_{i, t}=\alpha+\beta_{1} \cdot N P L_{i, t}+\beta_{2} \cdot \text { BOPO }_{i, t}+\beta_{3} \cdot \text { LNAsset }_{i, t}+\beta_{4} \cdot \text { GCG }_{\text {Variables }}, t+\varepsilon_{i, t}
$$

Where i indexes the bank, and t indexes the year (2013-2105). Performance is measured by ROA, NIM, and Tobin's Q. While GCG variables are measured by the eleventh variables listed in Table 2.

\section{Research Results and Discussion}

\subsection{Descriptive Statistics}

The outcomes of the descriptive statistics test for variables are shown in Table 2, Table 3, and Table 4 which provides information about all samples, big banks, and small banks respectively. The descriptive statistics results reveal that the banks in this study have low non-performing loan ratio, the average of expense ratio (BOPO) $86.01 \%$, the relatively small amount of ROA and NIM, and Tobin's Q value more than 1. Furthermore, in comparison to small banks, big banks have bigger non-performing loan. However, big banks have better in expense ratio value than small banks. Perhaps, that is the reason why the big banks have better profitability variables than the small banks. But, in term of Tobin's $Q$ value, big banks have a lower value than small banks.

Table 2. Descriptive statistic (All samples)

\begin{tabular}{lrrrrrr}
\hline \multicolumn{1}{c}{ N } & \multicolumn{1}{c}{ Mean } & \multicolumn{1}{c}{ Median } & \multicolumn{1}{c}{ Stdev } & \multicolumn{1}{c}{ Min } & \multicolumn{1}{c}{ Max } \\
\hline Asset & 114 & $108,891,306.31$ & $21,021,634.50$ & $202,045,567.40$ & $745,647.00$ & $910,063,409.00$ \\
NPL & 114 & $2.21 \%$ & $1.94 \%$ & $2.05 \%$ & $0.00 \%$ & $12.28 \%$ \\
BOPO & 114 & $86.01 \%$ & $87.83 \%$ & $17.76 \%$ & $9.27 \%$ & $173.80 \%$ \\
ROA & 114 & $1.46 \%$ & $1.36 \%$ & $1.79 \%$ & $-7.58 \%$ & $5.42 \%$ \\
NIM & 114 & $5.23 \%$ & $4.87 \%$ & $2.17 \%$ & $0.24 \%$ & $13.04 \%$ \\
Tobin'sQ & 108 & 1.07 & 1.03 & 0.16 & 0.83 & 1.77 \\
IB & 107 & 2.72 & 3.00 & 0.86 & 1.00 & 5.00 \\
BM & 94 & 14.28 & 8.00 & 14.60 & 3.00 & 64.00 \\
BEM & 70 & 12.01 & 12.00 & 7.87 & 2.00 & 38.00 \\
\%BMAtt & 88 & $86.98 \%$ & $91.83 \%$ & $14.35 \%$ & $50.00 \%$ & $100.00 \%$ \\
\%BEMAtt & 62 & $84.98 \%$ & $89.00 \%$ & $14.40 \%$ & $39.29 \%$ & $100.00 \%$ \\
AC & 108 & 3.91 & 4.00 & 1.10 & 3.00 & 8.00 \\
ACM & 105 & 12.57 & 11.00 & 8.41 & 2.00 & 43.00 \\
\%ACMAtt & 93 & $89.62 \%$ & $92.65 \%$ & $12.83 \%$ & $44.52 \%$ & $100.00 \%$ \\
RC & 106 & 4.21 & 4.00 & 1.39 & 2.00 & 8.00 \\
RCM & 103 & 9.49 & 7.00 & 6.78 & 2.00 & 35.00 \\
\%RCMAtt & 92 & $89.21 \%$ & $93.32 \%$ & $12.51 \%$ & $45.70 \%$ & $100.00 \%$ \\
\hline
\end{tabular}

Asset in IDR million. We do not have the balance number of data regarding not all information is provided in the annual report. 
Table 3. Descriptive statistic (Big bank)

\begin{tabular}{llrrrrr}
\hline & N & \multicolumn{1}{c}{ Mean } & \multicolumn{1}{c}{ Median } & \multicolumn{1}{c}{ Stdev } & \multicolumn{1}{c}{ Min } & \multicolumn{1}{c}{ Max } \\
\hline Asset & 68 & $179,293,598.81$ & $80,046,331.50$ & $237,438,751.45$ & $10,089,121.00$ & $910,063,409.00$ \\
NPL & 68 & $2.45 \%$ & $2.12 \%$ & $2.03 \%$ & $0.23 \%$ & $12.28 \%$ \\
BOPO & 68 & $84.25 \%$ & $84.53 \%$ & $18.70 \%$ & $53.00 \%$ & $173.80 \%$ \\
ROA & 68 & $1.67 \%$ & $1.73 \%$ & $2.05 \%$ & $-7.58 \%$ & $5.03 \%$ \\
NIM & 68 & $5.35 \%$ & $5.09 \%$ & $2.31 \%$ & $0.24 \%$ & $12.70 \%$ \\
Tobin'sQ & 68 & 1.07 & 1.03 & 0.14 & 0.90 & 1.77 \\
IB & 67 & 3.12 & 3.00 & 0.83 & 1.00 & 5.00 \\
BM & 58 & 18.66 & 11.00 & 17.07 & 4.00 & 64.00 \\
BEM & 48 & 13.44 & 12.00 & 8.72 & 2.00 & 38.00 \\
\%BMAtt & 56 & $83.75 \%$ & $86.01 \%$ & $14.08 \%$ & $52.38 \%$ & $100.00 \%$ \\
\%BEMAtt & 43 & $84.10 \%$ & $88.00 \%$ & $14.30 \%$ & $39.29 \%$ & $100.00 \%$ \\
AC & 67 & 4.19 & 4.00 & 1.22 & 3.00 & 8.00 \\
ACM & 66 & 14.62 & 13.00 & 8.49 & 4.00 & 43.00 \\
\%ACMAtt & 65 & $88.19 \%$ & $91.67 \%$ & $13.60 \%$ & $44.52 \%$ & $100.00 \%$ \\
RC & 66 & 4.68 & 4.00 & 1.47 & 3.00 & 8.00 \\
RCM & 65 & 10.62 & 9.00 & 7.30 & 4.00 & 35.00 \\
\%RCMAtt & 64 & $87.25 \%$ & $92.00 \%$ & $12.81 \%$ & $45.70 \%$ & $100.00 \%$ \\
\hline
\end{tabular}

Asset in IDR million. We do not have the balance number of data regarding not all information is provided in the annual report

Table 4. Descriptive statistic (Small bank)

\begin{tabular}{lrrrrrr}
\hline & N & \multicolumn{1}{c}{ Mean } & \multicolumn{1}{c}{ Median } & \multicolumn{1}{c}{ Stdev } & \multicolumn{1}{c}{ Min } & \multicolumn{1}{c}{ Max } \\
\hline Asset & 46 & $4,818,352.18$ & $4,233,021.50$ & $2,934,893.19$ & $745,647.00$ & $9,769,591.00$ \\
NPL & 46 & $1.86 \%$ & $1.18 \%$ & $2.05 \%$ & $0.00 \%$ & $8.90 \%$ \\
BOPO & 46 & $88.60 \%$ & $90.56 \%$ & $16.12 \%$ & $9.27 \%$ & $110.20 \%$ \\
ROA & 46 & $1.16 \%$ & $1.08 \%$ & $1.27 \%$ & $-1.58 \%$ & $5.42 \%$ \\
NIM & 46 & $5.05 \%$ & $4.81 \%$ & $1.95 \%$ & $2.16 \%$ & $13.04 \%$ \\
Tobin'sQ & 40 & 1.08 & 1.02 & 0.18 & 0.83 & 1.59 \\
IB & 40 & 2.05 & 2.00 & 0.32 & 1.00 & 3.00 \\
BM & 36 & 7.22 & 6.00 & 2.99 & 3.00 & 13.00 \\
BEM & 22 & 8.91 & 8.00 & 4.30 & 3.00 & 18.00 \\
\%BMAtt & 32 & $92.62 \%$ & $100.00 \%$ & $13.20 \%$ & $50.00 \%$ & $100.00 \%$ \\
\%BEMAtt & 19 & $86.95 \%$ & $93.00 \%$ & $14.82 \%$ & $57.41 \%$ & $100.00 \%$ \\
AC & 41 & 3.44 & 3.00 & 0.63 & 3.00 & 5.00 \\
ACM & 39 & 9.10 & 7.00 & 7.13 & 2.00 & 37.00 \\
\%ACMAtt & 28 & $92.94 \%$ & $98.17 \%$ & $10.31 \%$ & $57.81 \%$ & $100.00 \%$ \\
RC & 40 & 3.43 & 3.00 & 0.78 & 2.00 & 5.00 \\
RCM & 38 & 7.55 & 6.00 & 5.34 & 2.00 & 29.00 \\
\%RCMAtt & 28 & $93.69 \%$ & $98.00 \%$ & $10.73 \%$ & $48.48 \%$ & $100.00 \%$ \\
\hline
\end{tabular}

Asset in IDR million. We do not have the balance number of data regarding not all information is provided in the annual report

In addition, the results of descriptive statistics test for board directors reveals that the banks on average have 3 independent directors. Whether we examine the proportion of the number of board of director of all samples it is 
noted that around $46.7 \%$ banks have two independent directors and $51.4 \%$ has more than 2 people on the board of directors. It is also pointed out that big banks tend to have a more independent board of directors, more board meeting, and more board-executive meeting than the small bank. However, the small bank has better percentage meeting attendance than the big bank. In table 4, the numbers of data obtained are less than the data from the financial statement regarding not all information are released in the company annual report.

Moreover, the results also inform that the samples in this study have around 4 people as the audit committee and risk committee. The banks also conduct on average thirteen annual audit committee meeting and conduct on average ten annual risk committee meeting. It is noted that the bank percentage annual meeting attendance for both committees is around $90 \%$. Similar to the result in table 4, the big banks have more audit committee member and risk committee member than the small banks. The big banks also conduct more committee meeting than the small banks. The complexity of business and also the capability to hire more people and conduct more meeting becomes the reason why on average the big banks have more members in audit committee and risk committee as well as they have a more annual committee meeting. However, the percentage of annual meeting attendance of the big banks is lower than the small banks. Yet, the lower percentage of meeting attendance should not violate the central bank regulation that mentions the meeting of audit committee and risk monitoring committee could be held whether more than 50\% members attend the meeting include one independent board and an independent party (Indonesia, 2006).

Furthermore, before we did regression test for the models, we made multicollinearity test, test for normality, heteroscedasticity test, and autocorrelation test. The result of multicollinearity test shown in table 6 reveals that there is no multicollinearity among the dependent variables. We conducted Jargue-Berra test for examining the normality distribution of the residual. The results show that not all the model has normality distribution. Then, we assume that whether the data point is greater than 30, then the data would approximately follow the normal distribution. We then conducted a heteroscedasticity test. The results reveal that some models have heteroscedasticity phenomenon. This phenomenon was solved by using Eviews software. Finally, we conducted a Breusch-Godfrey autocorrelation test. The findings indicated that in some models have autocorrelation effect. Then, we made the assumption that no autocorrelation effect for short term years (Torres-reyna, 2007). These assumptions related to normally distribution and autocorrelation effect were a notable limitation of this study.

Table 5. Multicollinearity test result

\begin{tabular}{|c|c|c|c|c|c|c|c|c|c|c|c|c|c|}
\hline & $N P L$ & $\begin{array}{c}B O P \\
O\end{array}$ & $I B$ & $B M$ & $\begin{array}{c}\% B M \\
A t t\end{array}$ & $B E M$ & $\begin{array}{c}\% B E M \\
A t t\end{array}$ & $A C$ & $A C M$ & $\begin{array}{c}\% A C M \\
A t t\end{array}$ & $R C$ & $R C M$ & $\%$ RCM Att \\
\hline$N P L$ & 1.000 & & & & & & & & & & & & \\
\hline ВOРО & 0.532 & 1.000 & & & & & & & & & & & \\
\hline$I B$ & -0.108 & -0.327 & 1.000 & & & & & & & & & & \\
\hline$\% B M A t t$ & -0.196 & 0.103 & -0.353 & -0.372 & 1.000 & & & & & & & & \\
\hline$B E M$ & 0.141 & -0.052 & 0.217 & 0.519 & -0.473 & 1.000 & & & & & & & \\
\hline$\%$ BEM Att & -0.186 & 0.094 & -0.108 & -0.104 & 0.644 & -0.267 & 1.000 & & & & & & \\
\hline$\%$ ACM Att & -0.273 & 0.013 & -0.139 & -0.107 & 0.341 & -0.398 & 0.426 & -0.318 & -0.261 & 1.000 & & & \\
\hline$R C$ & 0.043 & -0.053 & 0.535 & 0.100 & -0.043 & 0.017 & 0.194 & 0.649 & 0.142 & -0.127 & 1.000 & & \\
\hline$R C M$ & 0.264 & -0.142 & 0.379 & 0.572 & -0.487 & 0.494 & -0.394 & 0.206 & 0.671 & -0.202 & 0.002 & 1.000 & \\
\hline$\%$ RCM Att & -0.113 & 0.095 & -0.225 & -0.112 & 0.279 & -0.411 & 0.290 & -0.240 & -0.165 & 0.618 & -0.193 & -0.133 & 1.000 \\
\hline
\end{tabular}




\subsection{Discussion}

We analyze the model using two-stage least square (2SLS) panel data regression. We conducted the Chow test and Hausman test to find whether the common model, the fixed effect model, or random effect model is a more appropriate fit for each model. In table 6 the results of regression for Independent Board of Directors reveals that the impact of external board of director on the bank performance varies among the model. The positive relationship between the number of independent board of directors and the net interest margin are found among big scale banks. It seems the board of directors bring their expertise to enhance the business and also ask the bank to increase the margin on loan (Al-Najjar, 2014; Mashayekhi \& Bazaz, 2008; Müller, 2014; Zhu et al., 2016). In addition, the result that indicates the positive impact of the board independence on the market value is found in small bank industry. This result supports the findings of Black and Kim (2012) study. Meanwhile, a non significant relationship between the independent board of directors and ROA are noted among the whole samples and among big banks. These results are similar to the previous study in Malaysia (Zabri, Ahmad, \& Wah, 2016). However, the negative impact of independent board of directors to ROA is found among the small bank industry. It means the business in small bank industry is unique that the independent board of directors could have a deficit informational experience among the board of directors (Cavaco et al., 2017). So, this study reveals for the small bank industry that even though the independent board of directors has the positive impact on the market value but they will have the lack of information that could obstruct the accounting based profit of the bank.

Table 6. Regression result for Independent Board of Director (IB)

\begin{tabular}{|c|c|c|c|c|c|c|c|c|c|}
\hline \multirow{2}{*}{ Variable } & \multicolumn{3}{|c|}{ ROA } & \multicolumn{3}{|c|}{ NIM } & \multicolumn{3}{|c|}{ Tobin's Q } \\
\hline & All & Big & Small & All & Big & Small & All & Big & Small \\
\hline Model & Fixed & Fixed & Fixed & Random & Fixed & Fixed & Fixed & Fixed & Random \\
\hline $\mathrm{N}$ & 107 & 67 & 40 & 107 & 67 & 40 & 105 & 67 & 38 \\
\hline Constant & 0.116 & 0.164 & 0.082 & 0.068 & 0.201 & 0.152 & 4.337 & 5.662 & 2.875 \\
\hline IB & $\begin{array}{l}0.001 \\
(0.892)\end{array}$ & $\begin{array}{l}-0.001 \\
-1.364\end{array}$ & $\begin{array}{c}-0.001 \\
(-1.885)^{*}\end{array}$ & $\begin{array}{l}0.003 \\
(1.587)\end{array}$ & $\begin{array}{c}0.003 \\
(1.921)^{*}\end{array}$ & $\begin{array}{l}-0.001 \\
(-0.663)\end{array}$ & $\begin{array}{l}0.018 \\
(1.006)\end{array}$ & $\begin{array}{l}0.016 \\
(0.766)\end{array}$ & $\begin{array}{c}0.057 \\
(1.814)^{*}\end{array}$ \\
\hline NPL & $\begin{array}{l}-0.015 \\
(-0.517)\end{array}$ & $\begin{array}{l}0.013 \\
(0.302)\end{array}$ & $\begin{array}{c}0.099 \\
(1.916)^{*}\end{array}$ & $\begin{array}{c}0.064 \\
(' 0.499)\end{array}$ & $\begin{array}{l}0.063 \\
(0.586)\end{array}$ & $\begin{array}{l}0.093 \\
(0.516)\end{array}$ & $\begin{array}{l}-0.322 \\
(-0.472)\end{array}$ & $\begin{array}{l}0.101 \\
(0.128)\end{array}$ & $\begin{array}{c}1.269 \\
(1.267)\end{array}$ \\
\hline $\mathrm{BOPO}$ & $\begin{array}{c}-0.097 \\
(-19.156)^{* * * *}\end{array}$ & $\begin{array}{c}-0.083 \\
(-10.106)^{* * * *}\end{array}$ & $\begin{array}{c}-0.139 \\
(-9.799)^{* * *}\end{array}$ & $\begin{array}{c}-0.035 \\
(-3.701)^{* * * *}\end{array}$ & $\begin{array}{l}-0.004 \\
(-0.290)\end{array}$ & $\begin{array}{c}-0.071 \\
(-2.017)^{*}\end{array}$ & $\begin{array}{l}0.126 \\
(0.978)\end{array}$ & $\begin{array}{l}0.192 \\
(1.286)\end{array}$ & $\begin{array}{c}-0.332 \\
(-1.797)^{*}\end{array}$ \\
\hline LN ASET & $\begin{array}{c}-0.001 \\
(-2.537)^{* * *}\end{array}$ & $\begin{array}{l}-0.004 \\
(-1.605)\end{array}$ & $\begin{array}{c}0.003 \\
(3.299) * * *\end{array}$ & $\begin{array}{l}0.000 \\
(0.068)\end{array}$ & $\begin{array}{c}-0.008 \\
(-2.875)^{* * * *}\end{array}$ & $\begin{array}{l}-0.003 \\
(-0.867)\end{array}$ & $\begin{array}{c}-0.199 \\
(-5.310)^{* * * *}\end{array}$ & $\begin{array}{c}-0.263 \\
(-5.173)^{* * * *}\end{array}$ & $\begin{array}{c}-0.107 \\
(-2.838)^{* * * *}\end{array}$ \\
\hline $\mathrm{R}^{2}$ & 0.984 & 0.991 & 0.976 & 0.138 & 0.980 & 0.952 & 0.932 & 0.938 & 0.404 \\
\hline Adj. $R^{2}$ & 0.973 & 0.983 & 0.948 & 0.104 & 0.964 & 0.897 & 0.886 & 0.889 & 0.332 \\
\hline $\mathrm{F}$ & $89.025 * * *$ & $134.289 * * *$ & $35.162 * * *$ & $4.085 * * *$ & $63.480 * * *$ & $17.256^{* * *}$ & $20.291 * * *$ & $19.398 * * *$ & $5.602 * * *$ \\
\hline Normality Test & $2454.817 * * *$ & 2.446 & $10.663 * * *$ & $97.388 * * *$ & $8.210^{* *}$ & $9.053 * *$ & $176.395 * * *$ & $363.281 * * *$ & 2.552 \\
\hline $\begin{array}{c}\text { Autocorrellation } \\
\text { Test }\end{array}$ & $19.223 * *$ & 2.131 & 3.634 & $30.832 * * *$ & 0.202 & 0.613 & $6.799 * *$ & 1.443 & 0.311 \\
\hline $\begin{array}{c}\text { Heteroscedasticsity } \\
\text { Test }\end{array}$ & $104.112 * * *$ & $24.820 * *$ & $35.313^{* * *}$ & $42.687 * * *$ & $27.183^{* *}$ & $31.370 * * *$ & 16.396 & 14.398 & 8.997 \\
\hline
\end{tabular}

Furthermore, we examine the impact of the board meeting on the performance. The proxy of the meeting is modified into four proxies. The previous study suggests the positive relationship between the meeting and the firm performance (H. I. Chou et al., 2013). In Table 7 the results reveal that board of director-executive meeting (BEM) has a positive impact to ROA. While, the attendance percentage of the board of director-executive meeting (\% BEM 
Att) has a positive impact on ROA and NIM among big banks. In addition, the percentage of attendance of board meeting (\% BM Att) has a positive relationship to ROA for a small bank and also have a positive impact to NIM for a big bank. So, from these results, we indicate that the meeting attendance variables are important in the banking industry in Indonesia. Yet, the board meeting variables failed to have a significant impact on the market value of the bank.

Moreover, this study found the important role of the audit committee as it is noted in table 8. For the whole sample, the number of the audit committee has a positive impact on ROA and NIM. The market value of small bank will be better as the number of audit committee increase. So, it supports the Munisi and Randoy (2013) findings that audit committee will enhance the performance by reducing the information asymmetry between insiders and outsiders. Moreover, This study also found a positive impact of the audit committee meeting to ROA supporting Salim et al. (2016) study. The market value of small bank will also higher as the percentage of audit committee meeting increase. These findings reveal the important role of the audit committee in the banking industry in Indonesia. However, we suggest further study as a confirmation of this study regarding the findings were not consistent whether the bank divided into the big bank and the small bank.

Finally, we also examine the impact of risk committee to the bank performance. In the previous study, the risk committee and the risk committee meeting will have a positive association with the performance. The risk committee members who have the capability in managing the risk will reduce the information asymmetry to the stakeholder. The risk appetite of the bank would be in line to the stakeholder that want more profit than the executives of the bank (Tao \& Hutchinson, 2013). However, even it is still not robust we found that the risk committee and the risk committee meeting have the negative association to the ROA. It seems the risk committee members in Indonesia tend to hide the risk regarding the severe crises in the past force the bank to default. So, the risk committee members tend to keep the bank business prudentially avoiding the threat of bankruptcy.

Table 7. Regression result (BM, BEM, \% BM Att, and \% BEM Att)

\begin{tabular}{|c|c|c|c|c|c|c|c|c|c|}
\hline \multirow{2}{*}{ Variable } & \multicolumn{3}{|c|}{ ROA } & \multicolumn{3}{|c|}{ NIM } & \multicolumn{3}{|c|}{ Tobin's Q } \\
\hline & All & Big & Small & All & Big & Small & All & Big & Small \\
\hline Model & Random & Fixed & Common & Fixed & Fixed & Common & Fixed & Fixed & $\begin{array}{c}\text { Commo } \\
\mathrm{n}\end{array}$ \\
\hline $\mathrm{N}$ & 53 & 36 & 17 & 53 & 36 & 17 & 53 & 36 & 17 \\
\hline Constant & 0.121 & 0.179 & 0.002 & -0.090 & -0.040 & -0.040 & 2.675 & 1.058 & 5.698 \\
\hline \multirow{2}{*}{$\mathrm{BM}$} & -0.000 & -0.000 & -0.000 & -0.000 & -0.000 & -0.001 & -0.001 & -0.000 & -0.020 \\
\hline & $(-1.155)$ & $(-0.986)$ & $(-0.304)$ & $(-0.374)$ & $(-1.107)$ & $(-0.349)$ & $(-0.897)$ & $(-0.745)$ & $(-1.486)$ \\
\hline \multirow{2}{*}{ BEM } & 0.000 & -0.000 & 0.001 & -0.000 & -0.000 & -0.001 & -0.001 & -0.001 & -0.015 \\
\hline & $(2.022)^{* * *}$ & $(-0.556)$ & $(2.198)^{*}$ & $(-0.690)$ & $(-1.593)$ & $(-0.243)$ & $(-0.724)$ & $(-0.296)$ & $(-1.551)$ \\
\hline \multirow{2}{*}{ \% BM Att } & 0.003 & -0.010 & 0.032 & 0.037 & -0.016 & -0.021 & -0.060 & -0.099 & -0.315 \\
\hline & $(0.614)$ & $(-1.569)$ & $(3.686)^{* * * *}$ & $(2.323)^{* * *}$ & $(-1.610)$ & $(-0.188)$ & $(-1.254)$ & $(-1.494)$ & $(-1.128)$ \\
\hline \multirow{2}{*}{$\begin{array}{l}\% \text { BEM } \\
\text { Att }\end{array}$} & -0.008 & 0.015 & -0.002 & -0.014 & 0.025 & 0.021 & -0.007 & 0.067 & -0.424 \\
\hline & $(-1.491)$ & $(2.339) * *$ & $(-0.239)$ & $(-0.782)$ & $(2.621)^{* * *}$ & $(0.709)$ & $(-0.105)$ & $(0.770)$ & $(-1.626)$ \\
\hline \multirow{2}{*}{ NPL } & 0.011 & -0.025 & 0.022 & -0.011 & -0.068 & 0.588 & 0.142 & -0.128 & 2.538 \\
\hline & $(0.328)$ & $(0.927)$ & $(0.355)$ & $(-0.133)$ & $(-1.749)$ & $(13.935)^{* * * *}$ & $(0.613)$ & $(-0.699)$ & (1.248) \\
\hline \multirow[b]{2}{*}{ BOPO } & -0.112 & -0.078 & -0.108 & 0.016 & 0.018 & -0.079 & -0.114 & -0.158 & -1.874 \\
\hline & $(-22.879) * * *$ & $(-10.667)^{* * * *}$ & $(-9.371)^{* * * *}$ & $(0.695)$ & (1.673) & $(-0.996)$ & $(-1.163)$ & $(-1.933)^{*}$ & $\begin{array}{c}(-5.112) \\
* * * *\end{array}$ \\
\hline \multirow{2}{*}{ LN ASET } & -0.001 & -0.005 & 0.005 & 0.006 & 0.004 & 0.011 & -0.084 & 0.009 & -0.131 \\
\hline & $(-1.155)$ & $(-1.537)$ & $(1.956)^{*}$ & $(0.684)$ & $(0.807)$ & $(0.428)$ & $(-1.451)$ & $(0.276)$ & $(-1.754)$ \\
\hline $\mathrm{R}^{2}$ & 0.967 & 0.998 & 0.974 & 0.981 & 0.996 & 0.538 & 0.986 & 0.987 & 0.846 \\
\hline Adj. $R^{2}$ & 0.961 & 0.995 & 0.953 & 0.939 & 0.987 & 0.179 & 0.955 & 0.955 & 0.726 \\
\hline $\mathrm{F}$ & $187.116^{* * * *}$ & $329.388 * * *$ & $48.299 * * *$ & $23.491 * *$ & $116.234 * *$ & 1.498 & $32.364 * *$ & $31.071^{* *}$ & $7.085^{* *}$ \\
\hline
\end{tabular}




\begin{tabular}{|c|c|c|c|c|c|c|c|c|c|}
\hline $\begin{array}{c}\text { Normality } \\
\text { Test }\end{array}$ & $7.424 * *$ & 5.678 & 1.945 & $\begin{array}{c}28.391 * * \\
*\end{array}$ & $10.308^{* * *}$ & $6.946^{* *}$ & $9.453 * * *$ & 0.141 & 0.515 \\
\hline \multicolumn{10}{|l|}{ Autocorrell } \\
\hline ation & 0.198 & $5.249 *$ & 1.014 & $7.38 * *$ & 3.186 & 0.419 & $8.081 * *$ & 0.213 & $6.751 * *$ \\
\hline \multicolumn{10}{|l|}{ Test } \\
\hline \multirow{2}{*}{$\begin{array}{c}\text { Heterosceda } \\
\text { sticsity }\end{array}$} & \multirow{3}{*}{30.673} & \multirow{3}{*}{8.704} & \multirow{3}{*}{7.227} & \multirow{3}{*}{27.180} & \multirow{3}{*}{4.563} & \multirow{3}{*}{$14.461 * *$} & \multirow{3}{*}{$49.920 * *$} & \multirow{3}{*}{$\begin{array}{c}20.801 * * \\
*\end{array}$} & \multirow{3}{*}{2.713} \\
\hline & & & & & & & & & \\
\hline Test & & & & & & & & & \\
\hline
\end{tabular}

Table 8. Regression result (AC, ACM, \% ACM Att, RC, RCM, \% RCM Att)

\begin{tabular}{|c|c|c|c|c|c|c|c|c|c|}
\hline \multirow{2}{*}{ Variable } & \multicolumn{3}{|c|}{ ROA } & \multicolumn{3}{|c|}{ NIM } & \multicolumn{3}{|c|}{ Tobin's Q } \\
\hline & All & Big & Small & All & Big & Small & All & Big & Small \\
\hline Model & Fixed & Fixed & Random & Fixed & Fixed & Fixed & Fixed & Fixed & Random \\
\hline $\mathrm{N}$ & 92 & 64 & 28 & 92 & 64 & 28 & 92 & 64 & 28 \\
\hline Constant & 0.122 & 0.090 & 0.153 & 0.185 & 0.115 & 0.131 & 4.108 & 6.003 & 3.141 \\
\hline $\mathrm{AC}$ & $\begin{array}{c}0.002 \\
(2.993)^{* * *}\end{array}$ & $\begin{array}{c}0.001 \\
(1.332)\end{array}$ & $\begin{array}{c}0.001 \\
(0.480)\end{array}$ & $\begin{array}{c}0.002 \\
(2.216)^{* *}\end{array}$ & $\begin{array}{c}-0.000 \\
(-0.016)\end{array}$ & $\begin{array}{c}0.006 \\
(0.452)\end{array}$ & $\begin{array}{c}0.012 \\
(0.716)\end{array}$ & $\begin{array}{c}-0.007 \\
(-0.353)\end{array}$ & $\begin{array}{c}0.082 \\
(\mathbf{8 . 6 3 8})^{* * *}\end{array}$ \\
\hline $\mathrm{ACM}$ & $\begin{array}{c}0.000 \\
(2.584)^{* *}\end{array}$ & $\begin{array}{c}0.000 \\
(1.023)\end{array}$ & $\begin{array}{c}0.001 \\
(1.619)\end{array}$ & $\begin{array}{c}-0.000 \\
(-0.576)\end{array}$ & $\begin{array}{c}-0.000 \\
(-1.142)\end{array}$ & $\begin{array}{c}-0.000 \\
(-0.131)\end{array}$ & $\begin{array}{c}0.001 \\
(0.577)\end{array}$ & $\begin{array}{c}0.001 \\
(0.237)\end{array}$ & $\begin{array}{c}0.002 \\
(1.703)\end{array}$ \\
\hline \% ACM Att & $\begin{array}{c}0.005 \\
(1.329)\end{array}$ & $\begin{array}{c}0.007 \\
(1.310)\end{array}$ & $\begin{array}{c}0.027 \\
(1.720)\end{array}$ & $\begin{array}{c}-0.016 \\
(-2.144)^{* * *}\end{array}$ & $\begin{array}{c}-0.000 \\
(-0.256)\end{array}$ & $\begin{array}{c}0.022 \\
(0.231)\end{array}$ & $\begin{array}{c}-0.043 \\
(-0.387)\end{array}$ & $\begin{array}{c}-0.127 \\
(-1.137)\end{array}$ & $\begin{array}{c}0.591 \\
(8.075)^{* * *}\end{array}$ \\
\hline $\mathbf{R C}$ & $\begin{array}{c}0.000 \\
(0.698)\end{array}$ & $\begin{array}{c}0.000 \\
(0.705)\end{array}$ & $\begin{array}{c}-0.001 \\
(-1.058)\end{array}$ & $\begin{array}{c}-0.001 \\
(-1.291)\end{array}$ & $\begin{array}{c}0.000 \\
(0.002)\end{array}$ & $\begin{array}{c}-0.004 \\
(-0.945)\end{array}$ & $\begin{array}{c}0.001 \\
(0.088)\end{array}$ & $\begin{array}{c}0.006 \\
(0.630)\end{array}$ & $\begin{array}{c}-0.003 \\
(-0.440)\end{array}$ \\
\hline RCM & $\begin{array}{c}-0.000 \\
(-1.823)^{*}\end{array}$ & $\begin{array}{c}-0.000 \\
(-1.418)\end{array}$ & $\begin{array}{c}-0.000 \\
(-1.796)^{*}\end{array}$ & $\begin{array}{c}-0.000 \\
(-0.704)\end{array}$ & $\begin{array}{c}0.000 \\
(0.555)\end{array}$ & $\begin{array}{c}-0.001 \\
(-0.741)\end{array}$ & $\begin{array}{c}0.001 \\
(0.206)\end{array}$ & $\begin{array}{c}0.002 \\
(0.393)\end{array}$ & $\begin{array}{c}-0.001 \\
(-0.916)\end{array}$ \\
\hline$\%$ RCM Att & $\begin{array}{c}-0.011 \\
(-2.379)^{* * *}\end{array}$ & $\begin{array}{c}0.002 \\
(0.363)\end{array}$ & $\begin{array}{c}-0.030 \\
(-2.706)^{* *}\end{array}$ & $\begin{array}{c}-0.012 \\
(-1.361)\end{array}$ & $\begin{array}{c}0.012 \\
(1.169)\end{array}$ & $\begin{array}{c}-0.041 \\
(-1.011)\end{array}$ & $\begin{array}{c}-0.062 \\
(-0.664)\end{array}$ & $\begin{array}{c}-0.042 \\
(-0.378)\end{array}$ & $\begin{array}{c}-0.370 \\
(-9.691)^{* * *}\end{array}$ \\
\hline NPL & $\begin{array}{c}-0.052 \\
(-2.100)^{* *}\end{array}$ & $\begin{array}{c}-0.038 \\
(-0.857)\end{array}$ & $\begin{array}{c}0.118 \\
(2.416)^{* *}\end{array}$ & $\begin{array}{c}-0.040 \\
(-0.471)\end{array}$ & $\begin{array}{c}0.009 \\
(0.115)\end{array}$ & $\begin{array}{c}-0.497 \\
(-0.726)\end{array}$ & $\begin{array}{c}-0.954 \\
(-1.181)\end{array}$ & $\begin{array}{c}-0.494 \\
(-0.558)\end{array}$ & $\begin{array}{c}-0.728 \\
(-1.086)\end{array}$ \\
\hline BOPO & $\begin{array}{c}-0.073 \\
(-9.788)^{* * * *}\end{array}$ & $\begin{array}{c}-0.071 \\
(-7.996)^{* * *}\end{array}$ & $\begin{array}{c}-0.111 \\
(-11.183)^{* * * *}\end{array}$ & $\begin{array}{c}0.009 \\
(0.957)\end{array}$ & $\begin{array}{c}0.006 \\
(0.413)\end{array}$ & $\begin{array}{r}-0.090 \\
(-1.500)\end{array}$ & $\begin{array}{c}0.371 \\
(2.188)^{* *}\end{array}$ & $\begin{array}{c}0.248 \\
(1.418)\end{array}$ & $\begin{array}{c}0.700 \\
(8.449)^{* * *}\end{array}$ \\
\hline LN ASET & $\begin{array}{c}-0.002 \\
(-7.942)^{* * * *}\end{array}$ & $\begin{array}{c}-0.001 \\
(-0.472)\end{array}$ & $\begin{array}{c}-0.002 \\
(-1.741)^{*}\end{array}$ & $\begin{array}{c}-0.007 \\
(-2.062)^{* * *}\end{array}$ & $\begin{array}{c}-0.004 \\
(-0.722)\end{array}$ & $\begin{array}{c}0.002 \\
(1.151)\end{array}$ & $\begin{array}{c}-0.191 \\
(-3.984)^{* * *}\end{array}$ & $\begin{array}{c}-0.274 \\
(-4.389)^{* * * *}\end{array}$ & $\begin{array}{c}-0.207 \\
(-14.818)^{* * * *}\end{array}$ \\
\hline $\mathrm{R}^{2}$ & 0.987 & 0.992 & 0.973 & 0.968 & 0.981 & 0.982 & 0.932 & 0.940 & 0.882 \\
\hline Adj. $\mathrm{R}^{2}$ & 0.974 & 0.983 & 0.959 & 0.936 & 0.960 & 0.882 & 0.863 & 0.870 & 0.823 \\
\hline F & $75.302 * * *$ & $113.805^{* * *}$ & $72.223^{* * *}$ & $30.134 * * *$ & $45.787 * * *$ & $9.817^{* *}$ & $13.548^{* * *}$ & $13.481 * * *$ & $15.003 * * *$ \\
\hline $\begin{array}{c}\text { Normality } \\
\text { Test }\end{array}$ & $12.424 * * *$ & $6.550 * *$ & 3.988 & $42.673^{* * *}$ & 13.692 & 1.5122 & $134.495^{* * *}$ & $331.167 * * *$ & 1.918 \\
\hline $\begin{array}{c}\text { Autocorrellation } \\
\text { Test }\end{array}$ & 0.869 & 1.043 & 0.000 & $10.163^{* * *}$ & 0.296 & 1.664 & $5.370^{*}$ & 3.681 & $9.466^{* * *}$ \\
\hline $\begin{array}{c}\text { Heteroscedasticsity } \\
\text { Test }\end{array}$ & $18.934 * *$ & 10.308 & 7.391 & $26.905^{* * *}$ & 13.928 & $17.974 * *$ & 6.221 & 4.390 & 5.508 \\
\hline
\end{tabular}

$* * *, * *, *=$ significance at the $1 \%, 5 \%$, and $10 \%$ respectively 


\section{Conclusions}

In this study, we examine the good corporate governance variables impact on bank performance in Indonesia. The variables are independent board (IB), the annual board meeting (BM), the percentage of annual board of director meeting attendance, the annual board-executive meeting (BEM), the percentage of annual board-executive meeting attendance, audit committee (AC), audit committee meeting (ACM), the percentage of annual audit committee meeting attendance, risk committee (RC), risk committee meeting ( $\mathrm{RCM}$ ), and the percentage of annual risk committee meeting attendance. The findings reveal that independent board has a positive impact on net interest margin among the big scale bank. However, among the small scale bank, the independent board of directors has the positive impact on the market value, but they will have the lack of information that could obstruct the accounting based profit of the bank. Moreover, the findings of this study also explain the important role of the board meeting for the accounting based profitability of the bank. The audit committee also has a positive impact on the accounting based performance as well as the market value only for the small bank. The audit committee meeting has a positive relationship to the ROA. However, the study could not found the positive impact of risk committee in the banking industry.

The implication of the findings in this study that the central bank of Indonesia and also the stakeholders could count on the independent board as well as the audit committee role in bank industry in Indonesia. These findings also support for the implementation good corporate governance in developing countries as it is mentioned in agency theories adequate monitoring activities are needed as well as appropriate incentives to the agent to achieve maximum value of the firm (Madison, Holt, Kellermanns, \& Ranft, 2015). Yet, the findings related to risk committee will encourage further study to confirm this result and the possibility of the impact of these variables on others variable such as the non-performing loan, compensation. This research also will shed light on the development of corporate governance in the banking industry that just releases the updated regulation in 2013.

\section{Acknowledgements}

The second author is a faculty of Economics, State University of Jakarta, Indonesia and also a recipient student in STUST Taiwan on the 3+1 Indonesian Directorate General of Higher Education (Dikti) and Elite Study in Taiwan (ESIT) Scholarship Fellowship.

The authors thank Gandung Amandani from CV. Independent Generation for preparing the raw data for this research.

\section{References}

Al-Najjar, B. (2014). Corporate governance, tourism growth and firm performance: Evidence from publicly listed tourism firms in five Middle Eastern countries. Tourism Management, 42, 342-351. http://doi.org/10.1016/j.tourman.2013.09.008

Arafat, M. Y., Warokka, A., Buchdadi, A. D., \& Suherman. (2013). Banking efficiency and performance: a test of banking characteristics in an emerging market. J. for Global Business Advancement, 6(1), 13-23. http://doi.org/10.1504/JGBA.2013.053475

Black, B., \& Kim, W. (2012). The effect of board structure on firm value: A multiple identification strategies approach using Korean data. Journal of Financial Economics, 104(1), 203-226. http://doi.org/10.1016/j.jfineco.2011.08.001

Brick, I. E., \& Chidambaran, N. K. (2010). Board meetings, committee structure, and firm value. Journal of Corporate Finance, 16(4), 533-553. http://doi.org/10.1016/j.jcorpfin.2010.06.003

Cavaco, S., Crifo, P., Rebérioux, A., \& Roudaut, G. (2017). Independent directors: Less informed but better selected than affiliated board members? Journal of Corporate Finance. http://doi.org/10.1016/j.jcorpfin.2017.01.004

Chou, H. I., Chung, H., \& Yin, X. (2013). Attendance of board meetings and company performance: Evidence from Taiwan. Journal of Banking and Finance, 37(11), 4157-4171. http://doi.org/10.1016/j.jbankfin.2013.07.028

Chou, T. K., \& Buchdadi, A. D. (2016). Bank Performance and Its Underlying Factors: A Study of Rural Banks in Indonesia. Accounting and Finance Research, 5(3), 55-63. http://doi.org/10.5430/afr.v5n3p55

Claessens, S., \& Yurtoglu, B. B. (2013). Corporate governance in emerging markets: A survey. Emerging Markets Review, 15, 1-33. http://doi.org/10.1016/j.ememar.2012.03.002

Coles, J. W., McWilliams, V. B., \& Sen, N. (2001). An examination of the relationship of governance machanisms to performance. Journal of Management, 27(1), 23-50. http://doi.org/10.1016/S0149-2063(00)00085-4

Dincer, H., Gencer, G., Orhan, N., \& Sahinbas, K. (2011). A performance evaluation of the Turkish banking sector 
after the global crisis via CAMELS ratios. In Procedia - Social and Behavioral Sciences (pp. 1530-1545). http://doi.org/10.1016/j.sbspro.2011.09.051

Duru, A., Iyengar, R. J., \& Zampelli, E. M. (2015). The dynamic relationship between CEO duality and firm performance: The moderating role of board independence. Journal of Business Research, 69(10), 4269-4277. http://doi.org/10.1016/j.jbusres.2016.04.001

Indonesia, B. (2006). Peraturan Bank Indonesia Nomor 8/4/PBI/2006 Tentang Pelaksanaan Good Corporate Governance Bagi Bank Umum (Bank Indonesia Regulation No. 8/4 / PBI / 2006 on Implementation of Good Corporate Governance for Commercial Bank). Retrieved from http://www.bi.go.id/id/peraturan/kodifikasi/bank/Documents/GCG Complete.pdf

Indonesia, B. (2016a). Arsitektur Perbankan Indonesia (Indonesian Banking Architecture). Retrieved January 1, 2016, from http://www.bi.go.id/id/perbankan/arsiteltur/Contents/Default.aspx

Indonesia, B. (2016b). PROGRAM PENINGKATAN KUALITAS MANAJEMEN DAN OPERASIONAL PERBANKAN. $\quad$ Retrieved January $1, \quad 2016, \quad$ from http://www.bi.go.id/id/perbankan/arsitektur/manajemen/Contents/Default.aspx

John, K., \& Senbet, L. L. W. (1998). Corporate governance and board effectiveness. Journal of Banking \& Finance, 22, 371-403. http://doi.org/10.1016/S0378-4266(98)00005-3

Liang, Q., Xu, P., \& Jiraporn, P. (2013). Board characteristics and Chinese bank performance. Journal of Banking and Finance, 37(8), 2953-2968. http://doi.org/10.1016/j.jbankfin.2013.04.018

Liu, Y., Miletkov, M. K., Wei, Z., \& Yang, T. (2015). Board independence and firm performance in China. Journal of Corporate Finance, 30, 223-244. http://doi.org/10.1016/j.jcorpfin.2014.12.004

Madison, K., Holt, D. T., Kellermanns, F. W., \& Ranft, A. L. (2015). Viewing Family Firm Behavior and Governance Through the Lens of Agency and Stewardship Theories. Family Business Review, 29(1), 65-93. http://doi.org/10.1177/0894486515594292

Mangunyi, E. E. (2011). Ownership Structure and Corporate Governance and Its Effects on Performance: A Case of Selected Banks in Kenya. International Journal of Business Administration, 2(3), 2-18. http://doi.org/10.5430/ijba.v2n3p2

Markonah, Cahaya, Y. F., \& Riwayati, H. E. (2016). The Effect of Banking Company Performance toward Good Corporate Governance Listed in Indonesia Stock Exchange. Procedia - Social and Behavioral Sciences, 219, 486-492. http://doi.org/10.1016/j.sbspro.2016.05.024

Mashayekhi, B., \& Bazaz, M. S. (2008). Corporate Governance and Firm Performance in Iran. Journal of Contemporary Accounting \& Economics, 4(2), 156-172. http://doi.org/10.1016/S1815-5669(10)70033-3

Mulili, B. M., \& Wong, P. (2011). Corporate Governance Practices in Developing Countries: The Case for Kenya. International Journal of Business Administration, 2(1), 14. http://doi.org/10.5430/ijba.v2n1p14

Müller, V.-O. (2014). The Impact of Board Composition on the Financial Performance of FTSE100 Constituents. Procedia - Social and Behavioral Sciences, 109, 969-975. http://doi.org/10.1016/j.sbspro.2013.12.573

Munisi, G., \& Randoy, T. (2013). Corporate Governance and Company Performance across Sub-Saharan African Countries. Journal of Economics and Business, 70, 92-110. http://doi.org/10.1016/j.jeconbus.2013.08.003

Pradhan, R. P., Arvin, M. B., Hall, J. H., \& Bahmani, S. (2014). Causal nexus between economic growth, banking sector development, stock market development, and other macroeconomic variables: The case of ASEAN countries. Review of Financial Economics, 23(4), 155-173. http://doi.org/10.1016/j.rfe.2014.07.002

Riaz, S., Liu, Y., \& Ahmad, M. I. (2016). Dividend Policy and Corporate Governance Perspective. Accounting and Finance Research, 5(3), 78-86. http://doi.org/10.5430/afr.v5n3p77

Roman, A., \& Şargu, A. C. (2013). Analysing the Financial Soundness of the Commercial Banks in Romania: An Approach based on the Camels Framework. Procedia Economics and Finance, 6(13), 703-712. http://doi.org/10.1016/S2212-5671(13)00192-5

Salama, F. M., \& Putnam, K. (2013). The impact of corporate governance on the financial outcomes of global diversification. International Journal of Accounting, 48(3), 364-389. http://doi.org/10.1016/j.intacc.2013.07.003

Salim, R., Arjomandi, A., \& Seufert, J. H. (2016). Does corporate governance affect Australian banks' performance? Journal of International Financial Markets, Institutions and Money, 43, 113-125. 
http://doi.org/10.1016/j.intfin.2016.04.006

Schultz, E. L., Tan, D. T., \& Walsh, K. D. (2010). Endogeneity and the corporate governance - performance relation. Australian Journal of Management, 35(2), 145-163. http://doi.org/10.1177/0312896210370079

Tan, Y. (2014). Corporate governance in the banking sector. In Performance, Risk and Competition in the Chinese Banking Industry (pp. 39-64). Elsevier. http://doi.org/10.1533/9781780634463.39

Tao, N. B., \& Hutchinson, M. (2013). Corporate governance and risk management: The role of risk management and compensation committees. Journal of Contemporary Accounting \& Economics, 9(1), 83-99. http://doi.org/10.1016/j.jcae.2013.03.003

Torres-reyna, O. (2007). Panel Data Analysis Fixed and Random Effects using Stata (v.4.2). Retrieved March 27, 2017, from https://www.princeton.edu/ otorres/Panel101.pdf

Zabri, S. M., Ahmad, K., \& Wah, K. K. (2016). Corporate Governance Practices and Firm Performance: Evidence from Top 100 Public Listed Companies in Malaysia. Procedia Economics and Finance, 35(October 2015), 287-296. http://doi.org/10.1016/S2212-5671(16)00036-8

Zhu, J., Ye, K., Tucker, J. W., \& Chan, K. (Johnny) C. (2016). Board hierarchy, independent directors, and firm value: Evidence from China. Journal of Corporate Finance, 41, 262-279. http://doi.org/10.1016/j.jcorpfin.2016.09.009 